\title{
Hari Raya Food and its Significance with Malays
}

\author{
Mohd Shazali Md. Sharif ${ }^{1}$, Mohd Salehuddin Mohd Zahari 2 , \\ Norazmir Md Nor ${ }^{2}$, Rosmaliza Muhammad 2
}

\author{
${ }^{1}$ Faculty of Hotel \& Tourism Management, \\ Universiti Teknologi MARA (UiTM), Selangor, Malaysia \\ ${ }^{2}$ Faculty of Health Sciences, Universiti Teknologi MARA (UiTM), Puncak Alam, 42300 \\ Selangor, Malaysia \\ shazali@salam.uitm.edu.my
}

\begin{abstract}
It is becoming a long tradition regardless generations for the Malay community to prepare and served traditional foods for Hari Raya celebration. Through observation and interview procedures, this paper describes the significance of traditional Hari Raya food from three Malay generation women's understanding of the process of Malay traditional Hari Raya food knowledge transfer. Charitable deeds, Social Bonding, and Memories are significant elements in the knowledge transfer processes. Majorities of informers noted that Hari Raya without the traditional food is nothing or did not bring any significant for the celebration. In other words, Hari Raya foods play important roles in cheering or complete the atmosphere of the festive celebration.
\end{abstract}

Keywords: Malay ethnic, Malay generation, Malay traditional food, Women

eISSN 2514-7528 @ 2018. The Authors. Published for AMER ABRA cE-Bs by e-International Publishing House, Ltd., UK. This is an open-access article under the CC BY-NC-ND license (http://creativecommons.org/licenses/bync-nd/4.0/). Peer-review under responsibility of AMER (Association of Malaysian Environment-Behaviour Researchers), ABRA (Association of Behavioural Researchers on Asians) and CE-Bs (Centre for EnvironmentBehaviour Studies), Faculty of Architecture, Planning \& Surveying, Universiti Teknologi MARA, Malaysia.

DOI: https://doi.org/10.21834/jabs.v3i10.308 


\subsection{Introduction}

Hari Raya is a religious celebration that marks the end of Ramadan, the Islamic holy month of fasting which is celebrated on the first day of Shawwal by Muslims across the world including the Malay community in Malaysia. This is a day where Muslim around the world shows a common goal of unity and blessing. In this greatness or blessing day, Muslims besides performing tasbeeh, tahmeed and takbir (perform religious chanting), performing morning Hari Raya prayer, they are also strongly urged to perform many other meaningful activities like asking parents and family forgiveness, visit the family grave yard, pay visit to family relatives and friends as well as entertain guests with Hari Raya foods and drinks. Foods also, to other activities plays a significant role in the Hari Raya celebrations and convey valuable meanings in strengthening the relationships among families, friends and communities.

Hari Raya food referred as food prepared and served particularly during the Malay culture and Muslim religious celebrations or globally known as Aid Fitri or Aid Adha. The Malays commonly celebrate this annual feast with varieties of foods and special dishes particularly the traditional one. Traditional Hari Raya food is, in fact, to have brought significant meaning to the Malays women generations in celebrating the festive religious celebration. Therefore, this paper describes the significance of traditional Hari Raya food based on the understanding of the process of Malay traditional Hari Raya food knowledge transfer within the three generations Malay women or mothers.

\subsection{Literature Review}

\subsection{Malay Traditional Food}

Traditional food is food that is differentiated through particular qualitative aspects and has a specific cultural identity (Jordana, 2000) while Kwik (2008b) contended that traditional food may be interpreted as describing a process that does not change. The Malay food, on the other hand, has its history of existence and the origin of its results in its unique characteristics to these days. There was unclearly written evidence as to when the tradition of Malay food culture exists (M. S. M. Sharif, Zahari, Nor, \& Muhammad, 2013). However, from the popular beliefs and based on the earliest record that Malay food culture started to emerge in the 15th century during the Malacca Sultanate and Malacca itself act as an important trade center in the Malay Archipelago (Hooker, 2003). Besides Sultanate of Malacca, the active participation in the spice trade which involved ingredients, cooking methods, recipes and eating decorum have created an important legacy in the Malay culinary or food culture traditions.

The active participation among the spice traders in Malaya, it contributed to the added value of Malay culinary culture traditions (M. S. M. Sharif, Nor, \& Zahari, 2013). In addition, the existing of Malay food culture was also heavily convinced by the Pattani culture of Thai lander whereby on the eighteenth century the northern states such Kedah, Perlis, Pulau Pinang and Perak including the two east coast states namely Kelantan and Terengganu were under the influence of Siamese monarchy which immensely powerful at the time 
(Hooker, 2003).

\subsection{Malay Traditional Hari Raya Food}

The festive food of the Malays or Malay traditional Hari Raya foods are commonly made out of rice like ketupat, ketupat palas, lontong, and lemang as the main staple food of the Malays is rice (Zain, 2009). Typically, the Malay traditional Hari Raya foods would be different from what ordinarily consumed during the usual days. Beef and chicken dishes have become the choice for the main dish to accompany ketupat, nasi impit and lemang throughout the festive celebration although in the past it were very hard and lavish to purchase beef and chicken (Anon, 1995). That's the reason that made Malay communities, and individual look forward for the traditional dishes during Hari Raya owing to the dishes were only prepared and served once a year on those days as the Malay community at that time could not afford to make such special dishes all year round (Md. Nor et al., 2012; M. S. Sharif, Supardi, Ishak, \& Ahmad, 2008).

A vast variety of food is present in this religious festival which incorporated the Malay culture and family tradition that has been practiced for generations. Traditional foods like ketupat, lemang, rendang, masak lodeh, lontong, and local cookies are usually prepared and served on that particular day (Anon, 1995).

\subsection{Food Practice Continuity}

Food practice is a way in which we are actively and comprehensively involved with all aspects of food, eating and gathering place around the table. It is a spiritual approach and independent of denomination or religion. In the simplest form, this is about the people together, break bread, connecting with each other, with food, and how we take in the nourishment of our bodies, hearts, and souls. Cultural practices also are the subject of discussion on the question of cultural life. If an ethnic group maintains official ethnic identity but loses its cultural practices or knowledge, resources, or the ability to continue their rise to the question whether the culture can truly live at all. It is worth reiterating that this paper is part of research to find out about understanding the process of Malay traditional Hari Raya food knowledge transfer within the three generations Malay women or mothers.

\subsection{Methodology}

In establishing the meaning of Malay traditional Hari Raya food among the three Malay women generations, a qualitative approach was employed. The rationale conducting a qualitative study is because it subjective in nature and reflecting on the perception in understanding the social and human activities (Merriam, 2009). The informants for this study were among three generations of Malay women, namely grandmother (age between 70 to 85 years old), mother (age between 50 to 69 years old) and daughter (age between 20 to 40 years old) within a family.

A Malay residential area in Selangor, Negeri Sembilan, Melaka, and Johor are the 
contextual setting for the study. A set of open-ended interview questions were developed to guide the informants to share their knowledge, experience and opinion on the meaning of traditional Hari Raya food. Before the actual interviews, six sets of informants (grandmother, mother, and daughter) were first identified through relatives and head of the Malay community in each area involved from selected settings. All respective set of informants were contacted via telephone for permission, date, times and venues for the interviews were to be conducted. Subsequently, the interviews were successfully conducted within two weeks. All the information was analyzed using thematic analysis based on Nvivo software.

\subsection{Results and Discussions}

\subsection{Informants' Profiles}

Eight groups of Malay women informants involved in this study. They consisted of the grandmother, mother, and daughter from selected families. For the interpretation, they recognized all Group informants. In short, the group of informants is simplified and presented in Table 1.

Table 1: Table should be titled

(Source: Cite the source)

\begin{tabular}{|c|c|c|c|c|}
\hline Informant & Age & Education & Occupation & State of Upbringing \\
\hline \multicolumn{5}{|c|}{ Group Informant 1} \\
\hline G.Mother & 68 & Primary School & Housewife & Johor \\
\hline Mother & 50 & SPM & Housewife & Johor \\
\hline Daughter & 32 & Diploma & Banker & Johor \\
\hline \multicolumn{5}{|c|}{ Group Informant 2} \\
\hline G.Mother & 70 & MCE & Retiree & Johor \\
\hline Mother & 53 & SPM & Clerk & Johor \\
\hline Daughter & 27 & SPMV & Supervisor & Johor \\
\hline \multicolumn{5}{|c|}{ Group Informant 3} \\
\hline G.Mother & 68 & Primary School & Housewife & Melaka \\
\hline Mother & 46 & SPM & Clerk & Melaka \\
\hline Daughter & 25 & Diploma & Asst.Admin. & Melaka \\
\hline \multicolumn{5}{|c|}{ Group informant 4} \\
\hline G.Mother & 69 & Primary School & Housewife & Melaka \\
\hline Mother & 50 & Standard 6 & Housewife & Melaka \\
\hline Daughter & 26 & STPM & Supervisor & Melaka \\
\hline \multicolumn{5}{|c|}{ Group Informant 5} \\
\hline G.Mother & 70 & Primary School & Housewife & N. Sembilan \\
\hline Mother & 51 & SPM & Clerk & N. Sembilan \\
\hline
\end{tabular}




\begin{tabular}{|lclll|} 
Daughter & 28 & Degree & $\begin{array}{l}\text { Bank } \\
\text { Officer }\end{array}$ & N. Sembilan \\
\hline \multicolumn{4}{c|}{ Group Informant 6 } \\
\hline G.Mother & 67 & Primary School & Housewife & N. Sembilan \\
Mother & 46 & Diploma & Teacher & N. Sembilan \\
Daughter & 29 & Degree & Teacher & N. Sembilan \\
\hline
\end{tabular}

In the subsequent section, the response given by the first generation or grandmother is indicated by Group Informant $A$ while information addressed by second generation or mother is specified by Group Informant $B$ and information given the third generation or daughter is reported by Group Informant $C$. Below were some of the responses given by informants. The subsequent section interprets the informers view on the significant of Hari Raya food to them. It aims to unveil the thoughtful and perception of three generations women on the important of Hari Raya food. Charitable Deeds and Social Bonding, and Memories are the two themes that can be revealed from the interpretation of the interview information.

\subsection{Charitable Deeds and Social Bonding}

Charity, preached by every religion of the world, is a way of bringing justice to society and is the essence of religion. Islam is, therefore, strongly urged the Muslim believers to commit and perform charity in many ways like that performing zakat, feeding the needy, helping the poor. Worth mentioning that during Ramadan Muslims are normally taking the opportunity to contribute money or foods for breaking fast and the peak of this righteous good deed is on the Hari Raya celebration. In line with that, it is becoming the norm to the Malay community to perform charity deeds henceforth serving their guests with traditional foods, delicacies, and drinks during the festive month of Syawal or Hari Raya celebration.

Besides charity deeds, Hari Raya foods are also considerably important as a social bonding or catalyst toward harmonious of the family members, friends, and community and between ethnics' group's togetherness. In other words, Hari Raya foods can develop close knit and create bonding between all those mentioned groups. The preparation of food with the family members, serving it to the guests and conversation through it often supplies a space for interaction and opens lines of communication that directly create the closeness of the relationship. In fact, the majority of the informers firmly believed that besides Hari Raya, food served in any events act as the mechanism that built relationship and togetherness among the individuals. Example of the transcription of the response is as follow:

"Indeed, there is no denying that the primary purposes of Hari Raya food preparation were to serve and share with family members and others... This is in fact response to the teachings of Islam which urged us to share the pleasure and happiness in various forms. Therefore, preparing and serving Hari Raya foods to the guests is a part of charity deeds which we all believed that reward will be given in the hereafter. That is the reason why all Malays during Hari Raya are holding an open house for their guests. You know...... besides looking for rewards performing this activity, to be specific food through consumption of it indirectly developed and strengthened the social bonding, relationship and 
togetherness among the families, relatives, neighbours, Muslim friends and even none Muslim friends. You should agree with me that these routines were practices by our ancestors or since Islam was embraced by the Malays. What should I say is that the function of food in the celebration cannot be flippantly looked?"

(Informant 1A)

\subsection{Memories}

Memory is referred to the sum totals of what we remember and gives us the capability to learn and adapt the previous experiences as well as to build the relationships. Some informants' revealed that the Hari Raya traditional dishes so much connected with the memories of their childhood. Their memorable values were associated with family members like a grandmother, grandfather, father, mother, and siblings who have passed away as they were directly involved in Hari Raya food preparation and celebration during their present. In another word, the Hari Raya foods are creating memories of being together with the family members in preparing and serving the dishes for a festive celebration. Below are some of their responses:

"I guess, the Hari Raya foods especially the traditional one...hmm... reminds me of my childhood. During that time, my sisters, brothers and I were enjoying ourselves and excited not only with our new clothing, shoes but the preparation of traditional food together with family members and relatives at the night of Hari Raya eve were so meaningful as we got to together in accomplishing the tasks. However, some of are no longer with us. That is the reason why whenever I look and prepare the traditional dishes reminds me of my late family members and strikes all those memories"

"Yes, traditional Hari Raya food besides others always recalls me on my grandmother. I still remember how my grandmother taught me to peel the onion, garlic and weaving the ketupat casing. Hari Raya traditional food preparation is where the imparting of knowledge took place my grandmother to all her granddaughter and children. This was the best time as everybody got together to prepare food. Look like just preparing food but it gave a lot of other significant you know........social bonding, togetherness among family members. That why ... when to preparing the traditional Hari Raya food it brings to mind of the kinds of my grandmother of sharing the food knowledge.

(Informant 6B)

Overall, traditional Hari Raya food could not be looked lightly, but it is too meaningful or brings significant sense not only to the women but also to the man as well regardless of their generation.

\subsection{Conclusion}

Women, regardless of generation, signify Malay traditional Hari Raya food as a continuation or manifestation of Malay food culture heritage. It has been practiced for ages and yet still continues to practice the culture during the festive celebration each year. The Malay women generation associate Charitable deeds, Social Bonding and Memories as motivation in preparing and serving the Malay traditional Hari Raya food that was commonly celebrated twice each year in Malaysia. They argued that the Hari Raya traditional foods even though not prepared in large quantities but it indirectly portrays the determination in continuing the 
traditions which ultimately represents the spirit of giving, gratitude and a sense of community while intensifying the family bonding. Therefore, preparation activities of the Malay traditional are considered to be a must and an obligation for each Malay family in celebrating the festive celebration. Hari Raya food preparation not only increases the understanding of the processes involved but also strengthens the acceptance as well as developing a sense of belonging to Malay traditional food particularly among the young generation. Therefore, the investigation of traditional Malay food, about modernization should continuously be undertaken.

\section{Acknowledgement}

This research was funded by the Ministry of Higher Education, Malaysia through Universiti Teknologi MARA under RAGS grant: 600-RMI/RAGS 5/3 (179/2012).

\section{References}

Anon, E. (1995). Malaysia Festive Cuisine. Kuala Lumpur: Berita Publishing Sdn. Bhd.

European Union. (2007). European Research on Traditional Foods. Belgium: Publications.europa.eu.

Fajans, J. (2006). Regional food and the tourist imigination in Brazil. Appetite, 47(3), 389.

Guthman, J. (2008). Bringing good food to others: investigating the subjects of alternative food practice. Cultural Geographies, 15(4), 431-447. doi: 10.1177/1474474008094315

Hooker, V. M. (2003). A Short History of Malaysia: Linking East and West. Singapore: Allen \& Unwin.

Jordana, J. (2000). Traditional foods: challenges facing the European food industry. [doi: DOI: 10.1016/S09639969(00)00028-4]. Food Research International, 33(3-4), 147-152.

Kierans, C., \& Haeney, J. (2010). The 'Social Life' of Scouse: Understanding Contemporary Liverpool through Changing Food Practices. Cultural Sociology, 4(1), 101-122. doi: 10.1177/1749975509356864

Anon, E. (1995). Malaysia Festive Cuisine. Kuala Lumpur: Berita Publishing Sdn. Bhd.

European Union. (2007). European Research on Traditional Foods. Belgium: Publications.europa.eu.

Kwik, J. C. (2008a). Traditional food knowledge: A case study of an Immigrant Canadian "foodscape". Environments, 36(1), 59-74.

Kwik, J. C. (2008b). Traditional Food Knowledge: Renewing Culture and Restoring Health. Master of Environmental Studies, University of Waterloo Canada, Ontario.

Md. Nor, N., Md. Sharif, M. S., Mohd. Zahari, M. S., Mohd. Salleh, H., Ishak, N., \& Muhammad, R. (2012). The Transmission Modes of Malay Traditional Food Knowledge within Generations. Procedia - Social and Behavioral Sciences, 50(0), 79-88. doi: 10.1016/j.sbspro.2012.08.017 
Merriam, S. B. (2009). Qualitative Research: A Guide to Design and Implementation. San Francisco: Jossey-Bass.

Munan, H. (1990). Cultures of the World Malaysia. Singapore: Times Books International.

Ohiokpehai, O. (2003). Promoting the Nutritional Goodness of Traditional Food Products. Pakistan Journal of Nutrition, 2(4), 267-270.

Sharif, M. S., Supardi, A., Ishak, N., \& Ahmad, R. (2008). Malaysian Food as Tourist Attraction Paper presented at the The 1st Malaysian Gastronomic - Tourism Conference.

Sharif, M. S. M., Nor, N. M., \& Zahari, M. S. M. (2013). The Effects of Transmission of Malay Daily Food Knowledge on the Generation Practices. Procedia - Social and Behavioral Sciences, 85(0), 227-235. doi: http://dx.doi.org/10.1016/j.sbspro.2013.08.354

Sharif, M. S. M., Zahari, M. S. M., Nor, N. M., \& Muhammad, R. (2013). How could the Transfer of Food Knowledge be Passed down? Procedia - Social and Behavioral Sciences, 105(0), 429-437. doi: http://dx.doi.org/10.1016/j.sbspro.2013.11.045

Su-Lyn, T. (2003). Malaysia \& Singapore: World Food: Lonely Planet.

Trichopoulou, A., Soukara, S., \& Vasilopoulou, E. (2007). Traditional Foods: A Science and Society Perspective. [doi: DOI: 10.1016/j.tifs.2007.03.007]. Trends in Food Science \& Technology, 18(8), 420-427.

Zain, S. (2009). The Malays Sejarah Melayu: A History of a Malay Peninsula (Vol. 2013). Singapore: htm. 